\title{
The Role of Faculty Members at Al-Balqa Applied University in the Development of Educational Creativity among Their Students
}

\author{
Dr. Jamal Fawaz Mansour Al Omari \\ Assistant Professor, Department of Basic Science \\ Princess Rahma University College, Jordan \\ E-mail: jamalalomari2000@yahoo.com
}

Prof. Adnan Abdul Salam Adayleh

Dean of Student Affairs, Al-Balqa Applied University, Jordan

Dr. Ahmad Abdulhameed Aufan Al-Makahleh

Assistant Professor, Department of Special Education, Al-Balqa Applied University

Princess Rahma University College, Jordan

Mr. Mujahed Hani Al Tahrawi

Lecturer, Department of Basic Science, Al-Balqa Applied University, Jordan

Mr. Obaid AbdelKarim Obeid Sabayleh

Lecturer, Department of Special Education, Al-Balqa Applied University, Jordan

Received: October 10, 2011 Accepted: December 14, $2011 \quad$ Published: December 31, 2011

doi:10.5296/ije.v3i2.1284 URL: http://dx.doi.org/10.5296/ije.v3i2.1284 


\section{Abstract}

This study aims to indicate the role of faculty members in the development of creativity among their students. It has to answer the following question:

What is the role of faculty members at Al-Balqa Applied University in the development of creativity among their students?

The group of the study consisted of all faculty members at the University, their total number was (727) members. The results have shown the following:

1- The overall arithmetic average for the role of faculty members in the development of creativity among college students has reached (3.11), which considered an intermediate level. 2- The reasons behind the differences of views amongst faculty members in the University regarding the development of creativity are connected with the following variables: Gender, field of specialization and teaching experience.

The most important methods of developing creativity among University students, from the viewpoint of faculty members are as follows:

1- The provision of financial allocations.

2- Reducing teaching costs.

3- Encouraging their participation in scientific conferences.

The study group recommended certain procedures according to its results. They can be briefed using the following.

Keywords: Role, Creativity, Faculty members and universities 


\section{Introduction}

The world has recently witnessed a tremendous development in all scientific fields. It affected various issues, particularly in the educational field, where the university's role changes depending on various international developments. The role of the university is no longer limited to providing information and knowledge, it goes beyond that to the development of various aspects in the personality of the individual to be able to learn, research, innovate and create. In addition, Modern University seeks to achieve integrated development of the student's personality in the following aspects: Cognition, emotion and skills. And therefore the student will learn how to think and how to be a creative researcher; that's what faculty members should develop among students in order to reach the highest level of creativity and innovation in various fields.

The current era is the era of knowledge, science and technology. It is characterized by rapid change; so it is important for the individual to be creative and innovative today, and this applies to educational institutions as well in order to go along with the changes and developments that occur in the external environment and to ensure its survival and growth in its work. Creativity is one of the core activities and missions of the organizations where there is an urgent need for the existence of effective learning to achieve intellectual development through the development of thinking skills among students who learn in such institutions. Studies related to this subject have shown that the output of pre-university education system is almost disappointing; the knowledge of many students who have finished high school does not exceed the limits of memorization (without understanding). (Al Sirn, 2000).

This era needs talented and creative brains that are able to adjust their own circumstances and needs along with the change that occurs in all environments, in order to go along with current development and provide a new and unique shape in various fields. We live in an era where science and knowledge ideas emerge rapidly, once there's a new idea, the technicians will apply it using modern invention. Talented and creative people are now the greatest hope in solving the problems that threaten humanity, which vary in quantity and quality. Talented are considered the national wealth and power towards building civilization; since the human wealth is the key factor for change, development and progress.

Faculty member at the University has a basic role in the development of creativity when discovered among his students. He can apply this through teaching and conducting scientific research. Universities should not be considered storages for science and knowledge, and the professors' role should be modified from simply lecturing and providing ready information to their students. It has become essential to make students master higher thinking skills; to be able to analyze and use most of the information which can be easily accessed nowadays, unlike students and researchers in the past. Hence, this study has been done to examine the role of faculty members in the development of creativity among their students.

\subsection{Creativity}

The interest in the creativity concept took place at the end of the thirties, and the first contributor in this field was the American Scientific (Schumpeter) who published his book in 
1939. He defined creativity as: "Turn by moving from the old to the new... To cancel and replace the old with a new one."

The expression "To innovate" was defined in one of the dictionaries as follows "To create something" (Al-Mawrid). In another one it was defined "To invent something unique" (Baalbaki, 1993). And in (Webster's Dictionary, 2006) "The ability to create or find something". The lexicon (Lisan Al Arab) for (Ibn Manthour) mentioned that creative is "Anything which comes first, as well as the magnificent names of God" (Ibn Manzoor, 1997). In the lexicon (Al-Waseet), to innovate is "to create something unique with no other similar, to reach the uttermost characteristic whether good or bad". Creativity can be described by going beyond ancients' methods through the development of new ones (Arabic Language Academy, Al-Waseet lexicon, 2005, p. 43). Finally, all lexicons agreed that creativity is the act of creating or inventing something unique with no other similar.

\subsection{What is creativity?}

Innovation is efficiency, power and willingness earned by structural-focused mentality, willingness, experience and information. Creativity is one of the secrets behind success in the fields of life, and enables the individual to discover new methods that can contribute in changing the world and getting rid of repetitive habits. Creativity became the core component in changing and development; it has replaced regular knowledge and methods; as both of them became possible. In order to be able to use creativity, one must get rid of the ambiguity and consider it a way to use the brain and process information. (Alahmed, 2003).

\subsection{Classification of Creativity}

It's clear from the literature review and definitions provided that there are many creative categories; due to the differences in researchers' viewpoints, as well as their field of specialization and the subjects of their study, which was conducted regarding creativity in addition to the nature of environments and institutions. Below are some classifications that were adopted for creativity:

(The standard used for output or results, the standard of continuity according to his field and the degree of uncertainty and risk, field of specialization, modification impact, source, and targets). (Feldhusen, 1998)

\subsection{Levels of Creativity}

Creativity is an investment to the ideas, the natural resources and ones aspirations from needs and objectives (general or private). Human creativity comes from the compatibility of internal with external factors related to the environment and society. Internal elements are related to the mental activity and emotions, and occur as a result of certain influences in the universe. This activity depends on the sense and the level of thought, the individual will express such influences using the creativity method that is applicable to his needs and objectives. (Sobhi, 1992)

There are two different levels for creativity: 
i. Basic level, which is represented by creative talent, the innovation of new insights and providing a new, meaningful element. Such as the one represented by Einstein in his theory of relativity, which has provided a new field of understanding that was not created before.

ii. Secondary level, which is similar to the process of practical extensions of existing ideas, without affecting the substantial aspects of such concepts. (Hareem, 2003)

\subsection{Some Creative Skills and Measurement Methods}

Creativity includes an integrated set of essential creative capabilities, such as: Fluency, flexibility, originality in addition to the ability to detect problems; although some researchers consider detecting problems a motive rather than creativity. And finally it has been altered from the area of cognitive abilities to the area of capacity assessment, because it alerts us when a problem emerges and it is an assessment process only.

Depending on subsequent research and analysis, each capacity related to creativity is a complex one; means there are many capacities for fluency, flexibility as well as originality. The following is a breakdown of the basic creativity skills: Fluency, flexibility and originality.

\subsubsection{Fluency}

Fluency is the individual's ability to create the largest possible number of creative ideas during a limited time. Therefore, the creative person is characterized by ease, speed and quantity in creating ideas that can be proposed for a certain subject.

It is also defined as the individual's ability to create the largest possible number of appropriate responses that are related to special conditions during a specific period, ex. (Symbols, numbers. shapes, words and ideas). There are many forms of fluency, including the following:

i. Expressional Fluency: The individual's ability to recall the largest possible number of meaningful sentences, containing words given in the correct order, or that contains specific characters. One of the tests that measure this factor the test of four-word combination. The individual will be given the first letter in four words and will be requested to complete the words in a specific time in many ways, in order to create meaningful statements. (Al Serfi, 2003)

ii. Ideational Fluency: The individual's ability to quickly recall the ideas in response to a problem or situation in a certain time, it is considered the most important factor of fluency. The difference between ideational fluency and expressional fluency is that the former refers to creating ideas, while the latter refers to the ability to combine these ideas into words. One of the examples is the test in which the individual is requested to recall the largest possible number of ideas about a certain topic, or solutions to a specific problem, or providing titles for a story. (Campbell, 1985)

iii. Word Fluency:The act of creating words or phrases as they are in individual's mind. It refers to intuition through uttering words in a specific format in order to follow the instructions of the tests. Words meaning has an important role in Word Fluency. 
iv. Associational Fluency: The ability to create the largest possible number of words which meet certain conditions in terms of meaning, as well as the ability to give synonyms to a specific word. Fluency factor does not mean that individuals should work in a time limit. It means that the individual who can create a large number of ideas in a limited time will have a greater chance to generate valuable ideas in general. (Ahmad, 1981)

\subsubsection{Flexibility}

The ability to change one's mentality or ideas. There are two major factors in Flexibility:

i. Adaptive Flexibility: The person's ability to change his mentality when attempting to solve a specific problem, and can be seen as the positive part of this adjustment. Flexible mentality has certain ideas opposite to strict-minded individual.

ii. Spontaneous Flexibility:The ability to create various ideas related to a specific situation, it can be measured using irregular usages, such as using the newspaper in different things other than reading it. There are other ways that can be used to measure this type of flexibility; for example, detecting how many times the individual switched from one idea to another or from one type of content to another, or through counting different types of ideas and images created by the person. Flexibility appears clearly between artists and authors through their success in the production of a variety of creations which do not belong to a single type.

\subsubsection{Originality}

One of the most important creative capabilities, which mean to pursue the production of new non-redundant ideas or images. It refers to the (Origin) concept; so we can call the image, idea or activity "Original" if it has not been created before. Originality can be measured using many ways, for example, the standards used for Guilford stories, impossible (imaginary) things or results, and for stories headlines. In this standard, the person will be given a short story and asked to mention all possible headlines related to it. The result is related to the number of non-conventional headlines of (low repetition feature), which the person allocates to the story, and it should be of high value from the literature view. (Serfi, 2003)

In the test related to impossible (imaginary) things or results, the person is requested to mention what will happen if something impossible happened, such as: What will happen if the science invented spectacles that can be used to read people's minds. The result is related to the number of unique ideas that are provided in response to this question.

Originality can be measured also using "Torrance battery". It depends on drawing certain shapes using simple lines or circles. The person will be asked to complete them by adding lines to form unique shapes. This standard has a unique way.............

\subsubsection{Types of creativity}

He has (Taylor) dividing the to different types are:

1) Creative expressive (Expressive Creativity): and in which the originality and efficiency at little importance. 
2) Productive creativity (Productive Creativity): which is linked to the development of a machine or product or service?

3) Inventive Creativity: and the provision of new methods.

4) Innovative creativity (Innovative Creativity): refers to the continuous development of ideas and results in the acquisition of new skills.

5) Creativity Emanations (Emergence Creativity): is a rare occurrence as required by the development of ideas and assumptions brand-new(Abdul Aziz, 2011).

\subsubsection{Previous studies}

i. Al-Ostath (Al-Ostath, 2004) has conducted a study about the role of university professor in the development of creative thinking among the students of Al-Aqsa University. The results referred to the differences in knowledge as one of the skills used for creative thinking among students; due to field of specialization as well as the impact of gender, specialty, and academic level.

ii. Al-Dmour (Al-Dmour, 2003) has conducted a study entitled "The Impact of Information Technology on Organizational Innovation: an Empirical Study on the Jordanian Public Shareholding Companies." The purpose of this study was to identify the use of information technology in the Jordanian industrial companies and its impact on organizational creativity. The study sample consisted of (384) members from various administrative levels. The most important findings of this study were the relationship between information technology as well as encouraging and implementing creativity. The study also indicated a relationship between information technology and the ways used to implement innovation among companies

iii. $\quad$ The study of Tahrawi (Tahrawi, 2007) entitled "University Professor and Creativity" aimed at defining the concept of creativity according to professors of Islamic University of Gaza and at identifying constraints of innovation in the University. The results showed that the concept of creativity according to the faculty members is as follows:

"To come up with new things coming up, to come up with unknown things, to use non-traditional thinking, to think in a unique way, to think in a modern way, to deal with issues in an unusual manner in addition to rearranging phrases to show meaning. One of the most important obstacles to innovation is the large number of students in classes; it has been asserted that such numbers do not allow students to innovate and use creative thinking; they even reduce the opportunity for discussion. Other factors contribute also such as insufficient resources (ex. Equipment, devices, tools, stationery, etc.), current events (ex. Political circumstances, Israeli raids, etc.). Moreover, the lack of motivation among many students, and lack of incentives (for students and teachers) affect creativity in a negative way.

iv. The study of (HAO Binbin, WANG Chunhong, 2008) entitled "The Thinking about Creative Education of Colleges" defined creativity as the continuous improvement of Chinese economic construction and the social development, which has increasingly become a core problem concerned by colleges to train the high-quality expertise with creative capability. This, for instance, has occurred in china at certain time where creative education has 
increasingly become an important subject concerned by the universities. This paper carried out in-depth analysis and discussion about the Specific initiatives of our country colleges implementing creative education.

v. The study of (MLi-Juan Ren, \& Zheng Tang, 2008) entitled "An Exploration of Creative Talents Training". The ways to train creative talents are put forward by an analysis of talents-training mode, individual development, creative thinking and the optimization of teaching process.

vi. In the study of Al-Zubaidi (Al-Zubaidi, 2009) entitled "The Role of University Curriculum in the Development of Creative Thinking for Students in light of the Challenges of the Era" showed that there is a great role for university administration and professors in the development of educational creativity among students by allowing them to participate in scientific conferences, following modern teaching methods and encouraging students to conduct survey, research, as well as experiments.

vii. In the study of Abu Khater (Abu Khater, 2010) entitled "The Role of the University in the Development of Creativity for Students in light of the Sunnah" showed that university professors accomplished their role in the development of creativity among their students in light of the Sunnah at a percentage of 68\%. The results also showed statistical differences in the role of university professors due to gender and field of specialization. There are no differences related to the cumulative GPA for the student.

Studies related to pre-university education have highlighted the important role of faculty members in the development of creative thinking among students, such as the study of Shdeifat (Shdeifat, 2009) and the study of Balwani (Balwani , 2010) and others.

Previous studies have shown the importance of libraries as one of the motivating factors for creativity, such as the study of Hela (Hela, 1994) in which he pointed out that there is an important role for university professors in the development of creativity from the students' viewpoint.

Similar studies are: Nur (Nur , 1998), Rubin (Rubin, 1998), Al-Ostath (Al-Ostath, 2004), Tahrawi (Tahrawi, 2007), Al-Zubaidi (Al-Zubaidi, 2009), and Abu Khater (Abu Khater, 2010) Their findings highlighted the need for new teaching methods to enable students to be creative, in addition to the importance of creativity in the educational institutions.

What distinguishes this study is that it is the first Jordanian study conducted in Jordanian universities that researches about the role of faculty members in the development of creativity among students, whereas previous studies surveyed the viewpoints of students themselves and not faculty members, it is also characterized by the sample and group of study.

Researchers benefit from previous studies in respect of their starting point, which was related to the studies of innovation. Creative individuals are considered as a national asset that needs motivation. 


\section{Problem Related to the Study}

Many studies have addressed the impact of technological impact in the types of educational creativity, and many aspects varied in the study of technology and its relationship with creativity. So it's important to consider the role of research and development activities and to provide educational innovations in the educational process. However, the Arabian and Jordanian Studies in the field of higher education, do not address this issue with the required attention and study, and the fact of research and development activities in the area of educational creativity in the Arab world in general, and Jordan in particular, needs analytical \& detailed study, as well as attention from the senior management to support them and provide what requires to achieve its objectives of providing various innovations which improve the level of education.

Because of that there was a need for a strategic planning for creativity by taking into accounts the variables and environmental factors with their impact on certain objectives related to creativity, since it requires a long time to achieve its objectives. During the primary survey, it was observed that the creativity in most of our institutions is not accomplished in accordance with a strategic perspective. Accordingly, the problem of the study will be discovered by answering the following question:

\section{What is the role of faculty members at Al-Balqa Applied University toward the development of creativity among their students?}

Questions Related to the Study: The study aims to identify the role of faculty members at Al-Balqa Applied University in the development of educational creativity among their students. It has to answer the following questions:

i. What is the role of faculty members at Al-Balqa Applied University in the development of educational creativity among their students, from the viewpoint of faculty members themselves?

ii. Are there any statistical differences that are connected with (gender, field of specialization and teaching experience) between faculty members at the University, with regard to educational creativity among their students?

iii. What are the ways required to develop creativity among University students, from the viewpoint of faculty members themselves?

\section{Objectives of the Study:}

The study aims to achieve the following:

i. Identifying the role of faculty members at the University in the development of educational creativity among their students.

ii. Detecting any statistical differences that are connected with (gender, field of specialization and teaching experience) between faculty members at the University, with regard to developing educational creativity among their students. 
iii. Stating of the viewpoints of faculty members regarding the ways that can be used to develop creativity among students.

\section{The Importance of the Study}

The importance of the study is related to two main points:

-Theoretical Importance. It can be explained through the following:

i. The importance of the subject of study, which can be defined through the concept of educational creativity among the students. The student here is the most important factor in the educational process.

ii. Since the current era is characterized by rapid change in various fields, administrative organizations have encountered many challenges and environmental issues. In order to be able to survive and grow, educational institutions should get along with rapid changes in technology through achieving creativity in teaching and learning process.

iii. The importance of creativity subject becomes clear through creating a new type of competition called "Creative / Innovation Competition". The concept of this competition is to provide new ideas which support institutions' superiority and ensure their growth in an environment full of rapid variables. Therefore, institutions intend to use a variety of means and methods that enable them to provide new forms related to education or developing them as soon as possible, taking into account graduating students with good knowledge at the lowest cost. Therefore, it is important to make innovation an integral part in developing the educational process.

Practical Importance. It can be explained through the following:

i. The results of this study will have new additions to the previous studies which can enrich the Arabic library.

ii. Officials in the University can benefit from its results; through the provision of a general perception for the development of educational creativity among students.

iii. The results of this study may lead to new studies related to creativity development that is highly recommended.

\section{Determinants of the Study}

i. Determinants related to human factor: Which is represented by the faculty members working at Al-Balqa Applied University since the academic year 2009/2010.

ii. Determinants related to Time: This study was implemented during the academic year 2009/2010.

iii. Determinants related to place: This study was confined to literary and scientific colleges. One literary and one scientific college were selected.

iv. Determinants related to the method used in the study: which was identified through terms used by researchers in this study. 


\section{Procedural Definitions related to Terms of the Study}

\subsection{Role}

To which extent faculty members contribute in the development of creativity among their students. It can also be defined through the tasks and responsibilities expected from the faculty members, in order to achieve the educational goals in the University.

\subsection{Faculty Members}

The instructors at the University that are appointed according to one of the following levels: Professor, Associate Professor, Assistant Professor, And Teacher. (Al-Balqa Applied University, 2010)

\subsection{Innovation}

Innovation in the field of education is defined by (Torrance) as a process similar to scientific research that helps the individual to sense and be aware of the problem, weaknesses and gaps, search for solutions, forecasting and developing hypotheses, test its validity and make modifications to the results; until one reaches the creative output. (Jarwan, 2009)

\subsection{Al-Balqa Applied University}

Jordanian governmental University established in 1997 under the patronage of the royal family. It is located in Salt city. (Al-Balqa Applied University, 2010)

\subsection{Students}

All students enrolled in the second semester of the academic year 2009/2010 to obtain the Bachelor degree, males and females.

\section{Methods and Procedures}

This section deals with a description of the study category and sample, the tools used and the indications of its validity and stability, as well as of the study variables, procedures, and statistical methods that was used in concluding and analyzing results.

\subsection{Methodology of the study: It followed the descriptive approach}

\subsection{Study category}

It consisted of all faculty members at Al-Balqa Applied University. Their total number was (727) members. Table number (1) presents the distribution of study sample members according to study variables (Gender, field of specialization and teaching experience). 
Table number (1). Distribution of study category according to study variables (Gender, field of specialization and teaching experience)

\begin{tabular}{|l|l|l|l|}
\hline Variable & Level & Number & Percentage \\
\hline \multirow{3}{*}{ Gender } & Male & 633 & 87.07 \\
\cline { 2 - 4 } & Female & 94 & 12.93 \\
\hline \multirow{3}{*}{ Field of Specialization } & Literary & 244 & 33.56 \\
\cline { 2 - 4 } & Scientific & 483 & 44.66 \\
\hline \multirow{3}{*}{ Years of Teaching Experience } & $1-5$ & 168 & 23.11 \\
\cline { 2 - 4 } & $6-10$ & 387 & 53.23 \\
\cline { 2 - 4 } & 11 and above & 172 & 23.66 \\
\hline Total & $\mathbf{7 2 7}$ & $\mathbf{1 0 0}$ \\
\hline
\end{tabular}

\subsection{Sample of the Study}

It consisted of (73) faculty members at Al-Balqa Applied University. They were randomly selected by $10 \%$, and all their questionnaires were collected back. Table number (2) presents the distribution of study sample members according to study variables (Gender, field of specialization and teaching experience).

Table number (2). Distribution of study sample members according to study variables (Gender, field of specialization and teaching experience)

\begin{tabular}{|l|l|l|l|}
\hline Variable & Level & Number & Percentage \\
\hline \multirow{2}{*}{ Gender } & Male & 64 & 87.70 \\
\cline { 2 - 4 } & Female & 9 & 12.30 \\
\hline \multirow{3}{*}{ Field of Specialization } & Literary & 48 & 65.80 \\
\cline { 2 - 4 } & Scientific & 25 & 34.20 \\
\hline \multirow{3}{*}{$\begin{array}{l}\text { Years of Teaching } \\
\text { Experience }\end{array}$} & $1-5$ & 17 & 23.30 \\
\cline { 2 - 4 } & $5-10$ & 39 & 53.40 \\
\cline { 2 - 4 } & 11 and above & 17 & 23.30 \\
\hline \multicolumn{2}{|l|}{ Total } & $\mathbf{7 3}$ & $\mathbf{1 0 0}$ \\
\hline
\end{tabular}

\subsection{Tool of the Study}

The study relied on a questionnaire developed by researchers; through reading theoretical literature and previous studies that were concerned about the types, fields and importance of innovation, as well as getting some viewpoints from specialists in the field of university education in general and public education in particular.

Researches have formulated the draft of the questionnaire based on previous studies as well as the purpose of this study. The questionnaire consisted of (44) items and it finally was limited to (38) paragraphs after it was reviewed by scientific specialists \& a group of referees, and after applying the procedures of validity and stability. The questionnaire consisted of three parts. The first part represents personal information related to the individual, such as gender, field of specialization and teaching experience. The second part represented opinions, and the third part was an open question to the members of the study sample. The second part 
consisted of (38) paragraphs and certain importance were given to each paragraph according to (Likert five-parts scale) in order to estimate its validity. The numbers are respectively: Strongly agree (5), agree (4), neutral (3), decline (2), strongly decline (1).

\subsection{Validity of the Tool}

Used to verify the validity of the questionnaire, and to check its ability to measure what you want to measure. Researchers used the referees tool and asked for the reviews of (10) qualified and experienced referees in the field of creativity in Jordanian universities, to express their views in the tool in terms of: The compatibility of paragraphs to the field, the accuracy and integrity of the language, the clarity of the paragraphs, in addition to other observations; in order to deduce the validity and comprehensiveness of the paragraphs according to the purpose. Many of their comments were taken into consideration and modifications applied accordingly. However, the final version of the questionnaire was modified to (38) paragraphs after it was around (44). Thus, the observations of the referees as well as their modifications (ex. Deletion and addition) were considered a validity tool for implementing this study.

\subsection{Stability of the Tool}

In order to verify the stability of the tool, researchers used a method of testing and re-testing (Test-Retest) on a sample of the study category outside the original sample which consisted of (25) faculty members, and questionnaires have been collected back. After two weeks they re-applied the tool on the sample again. The stability coefficient between both tests was (0.84), and it was acceptable to conduct the study. The coefficient of (Cronbach alpha) was also applied to ensure consistency between the paragraphs; the amount was (0.88) which considered being acceptable as well.

\subsection{Study Procedures}

After verifying the validity and stability of the questionnaire, the researchers distributed questionnaires among (73) faculty members of the study sample.

The members were given instructions and guidance about how to express their opinions in the paragraphs through inserting (tick) where appropriate. They added points or observations and answer questions and inquiries made by some members of the sample; they were given enough time to answer the questionnaire. After a period of three weeks, questionnaires were collected in the same way. The data were inserted to computers in order to conclude results and analyze them.

\subsection{Variables of the Study}

The study included the following variables:

7.8.1 The independent variables which include:

1 - Gender: Male and female.

2 - Field of specialization: Scientific and Literary. 
3 - Experience: 1-5 years, 6-11 years, 11 years and above.

B- The dependent variable which includes: The viewpoints of study sample regarding the development of educational creativity at Al-Balqa Applied University.

\section{Results and Reviews of the Study}

8.1 The first question was: What is the role of faculty members in Al-Balqa Applied University in the development of educational creativity among their students, from their point of view? Researchers answered this question using arithmetic averages and standard deviations as illustrated in Table number (3).

Table number (3). Arithmetic averages and standard deviations for the responses of study sample members

\begin{tabular}{|c|c|c|c|}
\hline Number & Paragraph & $\begin{array}{l}\text { Arithmeti } \\
\text { c Average }\end{array}$ & $\begin{array}{l}\text { Standard } \\
\text { Deviation }\end{array}$ \\
\hline 1 & $\begin{array}{l}\text { Takes into account the differences between } \\
\text { students }\end{array}$ & 3.85 & 0.88 \\
\hline 2 & Seeks to develop self-confidence between students & 3.80 & 0.86 \\
\hline 3 & $\begin{array}{l}\text { Allows students to choose the scientific activity } \\
\text { they like to do }\end{array}$ & 3.79 & 0.69 \\
\hline 4 & Focuses on research and survey & 3.77 & 0.83 \\
\hline 5 & Allocates enough time for creative thinking & 3.75 & 0.73 \\
\hline 6 & Ask questions that stimulate creative thinking & 3.74 & 0.92 \\
\hline 7 & Focuses on the higher mental processes & 3.66 & 0.80 \\
\hline 8 & Provides creative students with feedback & 3.39 & 0.83 \\
\hline 9 & $\begin{array}{l}\text { Makes students aware of the importance of } \\
\text { creativity }\end{array}$ & 3.38 & 0.79 \\
\hline 10 & Asks questions that have several correct answers & 3.38 & 0.78 \\
\hline 11 & Uses the problem-solving method in teaching & 3.33 & 0.82 \\
\hline 12 & Encourages students to debate & 3.32 & 0.83 \\
\hline 13 & $\begin{array}{l}\text { Helps students to search for and understand the } \\
\text { meaning of related concepts }\end{array}$ & 3.30 & 0.85 \\
\hline 14 & Values the ideas of the students & 3.25 & 0.76 \\
\hline 15 & $\begin{array}{l}\text { Follows-up on new issues in the students' field of } \\
\text { specialization }\end{array}$ & 3.21 & 0.80 \\
\hline 16 & Directs students to exploit their free time & 3.21 & 0.79 \\
\hline 17 & $\begin{array}{l}\text { Allows psychological and mental freedom of the } \\
\text { lecture }\end{array}$ & 3.17 & .83 \\
\hline 18 & Directs students towards real-life problems & 3.16 & 0.83 \\
\hline 19 & Develops curiosity among students & 3.16 & 0.92 \\
\hline 20 & $\begin{array}{l}\text { Being open-minded to new and unique ideas from } \\
\text { his/her students }\end{array}$ & 3.11 & 0.80 \\
\hline 21 & Allows students the opportunity to self-learning & 3.11 & 0.82 \\
\hline
\end{tabular}




\begin{tabular}{|c|c|c|c|}
\hline 22 & Encourages to ask any questions or ideas & 3.10 & 0.79 \\
\hline 23 & Provides situations that require creative thinking & 3.09 & 0.90 \\
\hline 24 & $\begin{array}{l}\text { Provides activities for students and taking into } \\
\text { account their abilities and potential }\end{array}$ & 3.09 & 0.74 \\
\hline 25 & Provides an open and loving learning environment & 3.09 & 0.74 \\
\hline 26 & $\begin{array}{l}\text { Encourages students to exchange ideas about a } \\
\text { certain issue }\end{array}$ & 3.06 & 0.74 \\
\hline 27 & $\begin{array}{l}\text { Trying to exploit the potential of creative } \\
\text { students }\end{array}$ & 3.05 & 0.76 \\
\hline 28 & Directs students towards imagination and creativity & 3.01 & 0.74 \\
\hline 29 & $\begin{array}{l}\text { Allows creative students to help others in the } \\
\text { lecture }\end{array}$ & 2.97 & 0.40 \\
\hline 30 & Detects obstacles of creativity among students & 2.96 & 0.47 \\
\hline 31 & Accepts unfamiliar questions from students & 2.95 & 0.45 \\
\hline 32 & Makes students self-confident & 2.94 & 0.46 \\
\hline 33 & Provides incentives to creative students & 2.94 & 0.47 \\
\hline 34 & $\begin{array}{l}\text { Directs students to the way in which they can } \\
\text { benefit and use the information }\end{array}$ & 2.94 & 0.92 \\
\hline 35 & Accepts unique ideas & 2.93 & 0.34 \\
\hline 36 & Encourages students to generate new ideas & 2.82 & 0.40 \\
\hline 37 & $\begin{array}{l}\text { Raises serious issues that requires debate and } \\
\text { discussion }\end{array}$ & 2.33 & 0.34 \\
\hline 38 & Develops the spirit of adventure among students & 2.32 & 0.45 \\
\hline \multicolumn{2}{|r|}{ Total } & 3.11 & 0.80 \\
\hline
\end{tabular}

The table shows that the overall average of the role of faculty members in the development of creativity among college students has reached (3.11), which is an intermediate degree. Arithmetic averages ranges between (2.32-3.85), with a standard deviation ranges between (0.45-0.88) in intermediate and advanced degrees. The results showed that the faculty members focus on taking into account differences among students and encouraging them to search \& survey; as well as being adventurous and raising controversial issues which requires low level of debate.

The results of the study pointed out that the faculty members are doing their role in the development of creativity among students, especially in the field of creativity skills (ex. Fluency, flexibility, originality and details).

The results of the averages as presented in the table showed that (28) paragraphs of the questionnaire was with high average, which means that the faculty members are doing their job and the university environment is helpful which encourage creativity.

The results also showed the presence of (10) paragraphs with a low average. They should be highlighted besides allowing faculty members to apply them through providing a suitable environment and circumstances. Moreover, it should be noted that some subjects do not contain controversial issues. 
This result was compatible with the following studies: (Tahrawi, 2007), (Nur, 1998), (Rubin, 1998), (Al-Ostath, 2004), (Abu Khater, 2010), and (Al-Zubaidi, 2009).

8.2 The second question was: Are there statistical differences among the faculty members at Al-Balqa Applied University towards the development of educational creativity in their students due to field of specialization, gender and teaching experience?

Researchers answered this question using averages and standard deviations as illustrated in Table number (4); in order to indicate the role of faculty members in the development of educational creativity among their students.

Table number (4). Arithmetic averages and standard deviations for the responses of study sample members; according to study variables (Gender, field of specialization and teaching experience

\begin{tabular}{|l|l|c|c|c|}
\hline \multirow{2}{*}{ Variable } & \multirow{2}{*}{ Level } & \multicolumn{2}{|l|}{ Tool (as a whole) } \\
\cline { 3 - 5 } & & Number & $\begin{array}{l}\text { Arithmetic } \\
\text { Average }\end{array}$ & $\begin{array}{l}\text { Standard } \\
\text { Deviation }\end{array}$ \\
\hline \multirow{2}{*}{ Gender } & Male & 24 & 3.59 & 0.19 \\
\cline { 2 - 5 } & Female & 14 & 3.64 & 0.23 \\
\hline \multirow{2}{*}{$\begin{array}{l}\text { Field of } \\
\text { Specialization }\end{array}$} & Scientific & 23 & 3.59 & 0.22 \\
\cline { 2 - 5 } \multirow{2}{*}{$\begin{array}{l}\text { Years of Teaching } \\
\text { Experience }\end{array}$} & Literary & 15 & 3.60 & 0.18 \\
\cline { 2 - 5 } & $1-5$ & 7 & 3.57 & 0.21 \\
\cline { 2 - 5 } & $6-10$ & 20 & 3.55 & 0.18 \\
\hline
\end{tabular}

The results of Table number (5) show that there were no statistical differences at the level $(0.05 \alpha \geq)$ between the members of the study sample. The faculty members at Al-Balqa Applied University referred to two variables related to the development of educational creativity; gender and field of specialization. The results also indicated that there are statistical differences at level $(0.05 \alpha \geq)$ between the members of the study sample. The faculty members at Al-Balqa Applied University referred to one variable related to the development of educational creativity; teaching experience.

Table number (5). Shows that there are differences in the averages related to viewpoints of faculty members in Al-Balqa Applied University in the development of creative education among their students; due to the following variables: Gender, field of specialization and teaching experience. In order to show the statistical concept of such differences, "The analysis of three variance" (3 Away ANOVA) has been used as shown in Table number (5)

\begin{tabular}{|l|l|l|l|l|l|}
\hline Teaching Experience & 0,450 & 2 & 0,225 & 5,908 & $* 0,004$ \\
\hline What Went Wrong & 1,178 & 73 & 0,0357 & & \\
\hline Total & 1,486 & 68 & & & \\
\hline
\end{tabular}

In order to show the statistical concept of such differences, "The test of dimensional comparisons" has been applied to all paragraphs as shown in Table number (6). 
Table number (6). The analysis of (Sheveh) for the differences between arithmetic averages for the variable (Teaching experience). The table indicated that there are statistical differences at level $(0.05 \geq \alpha)$

\begin{tabular}{|l|l|l|l|l|}
\hline \multirow{2}{*}{ Level } & & $\mathbf{1 - 5}$ years & $\mathbf{6 - 1 1}$ years & $\mathbf{1 1}$ years and above \\
\cline { 2 - 5 } & $\begin{array}{l}\text { Arithmetic } \\
\text { Average }\end{array}$ & 3,57 & 3,55 & 3,74 \\
\hline $\mathbf{1 - 5}$ years & 3,57 & -------- & 0,02 & $0,17-$ \\
\hline $\mathbf{6 - 1 1}$ years & 3,55 & -------- & ----------- & $* 0,19-$ \\
\hline $\begin{array}{l}\mathbf{1 1} \text { years } \\
\text { and above }\end{array}$ & 3,74 & ----- & ----------- & ----- \\
\hline
\end{tabular}

Table number (6) presents the results of comparisons between averages compared with the teaching experience variable. The results indicated that there are statistical differences between those with the teaching experience of (6-11 years) and (11 years and above), the differences were in favor with those who have (11 years and above) of experience, and the arithmetic average reached (3.74), while the average for people with teaching experience (6-11 years) was equal to (3.55).

This means that all faculty members of different genders and fields of specialization are doing their role in the development of creative thinking among students. However, teachers with high level of experience (11 years and above) play a major role in the development of creativity among students; due to long years of teaching experience in universities which gives them a greater chance to apply the concept of creativity more than other faculty members.

This result was compatible with the following studies: (Tahrawi, 2007), (Nur, 1998), (Rubin, 1998) and (Al-Ostath, 2004); while it interferes with the result of (Abu Khater, 2010).

8.3 The third question was: What are the ways of developing creativity among the students of Al-Balqa Applied University, from the viewpoint of faculty members?

Researchers directed an open question to the members of the study sample; their answers are listed in Table number (7).

Table number (7) shows that the highest response rate for faculty members was related to the idea that "faculty members are demanding the provision of financial allocations to encourage the creativity of the students". This idea came in the first place with a repetitive hit of (66) and the percentage $25 \%$ of the study sample. The idea that came in the second place represented their demands to reduce teaching costs came with a repetitive hit of (55) and the percentage $20 \%$ of the study sample.

This result was compatible with the following studies: (Tahrawi, 2007), (Nur, 1998), (Rubin, 1998), (Al-Ostath, 2004) and (Abu Khater, 2010). 
Table number 7.

\begin{tabular}{|c|c|c|c|}
\hline No. & Paragraph & Percentage & Frequency \\
\hline 1. & $\begin{array}{c}\text { Budget allocation for student's } \\
\text { creative activities }\end{array}$ & $25 \%$ & 66 \\
\hline 2. & Reduce teaching expenses & $20 \%$ & 55 \\
\hline 3. & $\begin{array}{l}\text { Encourage participation in scientific } \\
\text { conferences }\end{array}$ & $7 \%$ & 17 \\
\hline 4. & $\begin{array}{l}\text { Providing financial and } \\
\text { administrative support to faculty } \\
\text { members }\end{array}$ & $5 \%$ & 15 \\
\hline 5. & $\begin{array}{c}\text { Conducting meetings about } \\
\text { creativity for students }\end{array}$ & $5 \%$ & 15 \\
\hline 6. & $\begin{array}{c}\text { Asking students to do creative } \\
\text { activities according to their interests } \\
\text { and desires }\end{array}$ & $5 \%$ & 15 \\
\hline 7. & Encourage scientific research & $4 \%$ & 12 \\
\hline 8. & Reciprocal visits between students & $3 \%$ & 10 \\
\hline 9. & $\begin{array}{l}\text { Respect the viewpoints of creative } \\
\text { students and adopting them }\end{array}$ & $4 \%$ & 11 \\
\hline 10. & $\begin{array}{c}\text { Conducting scientific competitions } \\
\text { in order to develop creativity among } \\
\text { students }\end{array}$ & $3 \%$ & 9 \\
\hline 11. & $\begin{array}{c}\text { Conducting meetings between the } \\
\text { universities administration, faculty } \\
\text { members and students }\end{array}$ & $2 \%$ & 8 \\
\hline 12. & $\begin{array}{l}\text { Allow students to express their } \\
\text { views and scientific points }\end{array}$ & $2 \%$ & 8 \\
\hline 13. & $\begin{array}{l}\text { Provide the necessary tools and } \\
\text { equipment for creativity }\end{array}$ & $2 \%$ & 7 \\
\hline 14. & Consulting the local community & $2 \%$ & 6 \\
\hline 15. & Encourage scientific trips & $1 \%$ & 5 \\
\hline 16. & $\begin{array}{l}\text { Implementing creativity output for } \\
\text { all university students and make it } \\
\text { mandatory for graduation project in } \\
\text { the area of specialization }\end{array}$ & $1 \%$ & 5 \\
\hline
\end{tabular}

\section{Recommendations}

According to the result of this study, researchers have recommended the following:

i. Conducting a similar study on more samples which include other universities; in order to be able to publish the results.

ii. Encourage faculty members to engage their creative students in their practical research. 
iii. To make all civil society institutions involved in the preparation of curricula in order to create innovation.

iv. Applying tests related to creativity and talent to all students admitted in the first year; to distinguish creative and talented students.

v. Fulfilling all needs of the faculty member and encouraging him/her to use all resources available to raise the levels of creativity among students; and therefore reflected positively on the educational process.

vi. Training all faculty members to use strategies that foster creativity and innovation such as: Problem solving, discovery, games, brainstorming, survey and focusing on individuals in the education process.

\section{References}

Abdul Aziz, Said. (2011). Introduction to creativity, (Second edition.) House of Culture, Amman

Abu Khater, Mannar. (2010). University's Role in the Development of Creativity for Students in light of the Sunnah from their Point of View, unpublished Master thesis, Islamic University of Gaza, Palestine.

Al Baridi, Abdullah. (1999). Creativity Reflected Positively on Crisis. Riyadh, International House of Ideas.

Al Dmour, Fayrouz Musleh. (2003). The Impact of Information Technology on Organizational Innovation: A Practical Study of Industrial Public-Shareholding Jordanian Enterprises, unpublished Master thesis, University of Jordan, Faculty of Higher-Graduate Studies.

Al Lawzi, Mousa. (1999). Organizational Development as Basics and Modern Concepts, Amman, Wael House for Publication.

Al Qatawneh, Manar Ibrahim. (2000). Organizational Climate and its Impact on Creative Conduct: A Field Study of the Administrative Supervisors in the Ministries of Jordan, unpublished Master thesis, University of Jordan, Amman.

Al Rawi, Najeh. (1997). Brief on Japanese experience in spreading information related to technology, the Conference of Modern Trends in Contemporary Culture, Baghdad, Medical Complex.

Al Sarn, Raed Hasan. (2000). Innovation and Creativity Management: Technological Basis and Methods of Application. Damascus, Al Reda House.

Al Serafi, Mohammad Abdel-Fattah. (2003). Modern Management, first edition, Safa House for Publication and Distribution. Amman, Jordan.

Al Shamma'a, Khalil Mohammad Hasan. (1991). Management Principles, (first edition.) Baghdad. 
Al Shirawi, Adel. (1995). The Scientific Evidence for Total Quality Management, ISO, 900, Cairo, Arabian Scientific Information.

Al Tahrawi, Jamil. (2007). University Professor and Creativity, research presented in the third day regarding the university professor and quality issues in the Palestinian universities, Islamic University - Gaza.

Al-Balqa Applied University. (2010). Rules and Regulations Implemented in the University, the system of faculty members for the year number (42) of the year(2007), www.bau.edu.jo

Al-Ostath, Mohammed Hasan Mahmoud. (1994). The Role of university professor in the development of creative thinking among the students of Al-Aqsa University, unpublished Master thesis, University of Al-Aqsa, Gaza, Palestine.

Al-Zubaidi, Sabah. (2009). The Role of the University Curriculum in the Development of Creative Thinking in light of the Challenges in the Era, critical thought, "Scientific, Psychological and Educational Conference", Faculty of Education, University of Damascus, 25- 27 October, (2009).

Baalbaki, Munir. (1993). Al-Mawrid. Beirut, Dar Al Malayin.

Campbell, D. (1985). Take the Road to Creativity and Get off Your Dead End. Greensboro, INC, PP 87.99.

Feldhusen J. F. (1998). Creativity Teaching and Testing. Elsevier Science Ltd, Retrieved, March1, 2007, From: Education: The Complete Encyclopedia.

Harem, Hussein. (2003). Management of Organizations (General Perspective), (first edition). Al-Hamid House and Library, Amman, Jordan.

Hasan, Mr. Metwally, Gad, Ramadan Abdel-Azim. (1994). Some Aspects of Implementing Research and Development. Arab Journal of Management, Volume 16, first edition.

Heila, P. (1994). "The Creative and Innovative University Library" PhD, Dissertation Abstract, University of Pretoria, South Africa.

http://www.ibtesama.com/vb/showthread-t_10871.html

http://www.seiofbluemountain.com/upload/product/200909/2008jyhy01a43.pdf

Hussein, Ali. (2001). Creativity in Solving Problems. Riyadh, Jarir Bookstore.

Ibn Manthur, Abu Al Fadel Jamal Al Din Al Efriqi Al Masri. (2004). Lesan Al-Arab lexicon. (third edition.). Beirut, Sader House for Printing and Publication.

Jarwan, Fathi Abdullah. (2009). Talent, Excellence and Creativity. Amman, Dar Al-Fikr for Printing and Publication, Jordan.

Kanter, Rosette Mousa. (2001). "The Modern Director in the Middle Management", translated and displayed by Hussein Ammar, House Library Magazine, volume .

Kao John, the translation of Assaad Halim. (2001). Creativity in the Projects and Free 
Improvisation, first edition. Cairo, Al-Ahram Center.

Li-juan Ren \& Zheng Tan. (2008). An Exploration of Creative Talents Training. International education studies, Vol. No.2. pp1-3

Naoum, Namir Najib. (1990). The Management of Research and Development Projects to Fulfill the Needs of the Concerned Sector, Master thesis, University of Baghdad.

Noon, Donald. (2001). Creativity in Solving Problems. Damascus, Al Reda House.

Noor, Kadhim. (1998). The Role of the University Professor role in Stimulate Creativity and Development, Journal of the Association of Arab Universities, volume 33, Association of Arab Universities, Amman - Jordan.

Robben, s., and DAVID, A, D. (1998). "Fundamentals of Management: Essential Concepts and Applications", Second Edition, Prentice- Hall, USA.

Sternberg, Robert, J., and Grigorenko, Elena, L. (2002). The Theory of Successful Intelligence as a Basis for Education. Gifted Child Quarterly, Vol.46 (4): p 265-277.

Subhi, Taysir. (1992). Talent and Creativity: Diagnostic Methods and computerized tools. Jordan, Amman, Eshraf House for Publication and Distribution.

Torrance, E., and Myers, R. (1971). Creative Learning and Teaching. New York, Dodd Mead.

Webster, Danial. (2006). Webster third new international dictionary. Massachusetts, USA.

\section{Copyright Disclaimer}

Copyright reserved by the author(s).

This article is an open-access article distributed under the terms and conditions of the Creative Commons Attribution license (http://creativecommons.org/licenses/by/3.0/). 